\title{
Toxicity and nutritional inadequacy of Karenia brevis: synergistic mechanisms disrupt top-down grazer control
}

\author{
Rebecca J. Waggett ${ }^{1,2, *}$, D. Ransom Hardison ${ }^{1}$, Patricia A. Tester ${ }^{1}$ \\ ${ }^{1}$ National Ocean Service, National Oceanic and Atmospheric Administration, 101 Pivers Island Road, Beaufort, \\ North Carolina 28516-9722, USA \\ ${ }^{2}$ Present address: The University of Tampa, 401 W. Kennedy Blvd., Tampa, Florida 33606, USA
}

\begin{abstract}
Zooplankton grazers are capable of influencing food-web dynamics by exerting topdown control over phytoplankton prey populations. Certain toxic or unpalatable algal species have evolved mechanisms to disrupt grazer control, thereby facilitating the formation of massive, monospecific blooms. The harmful algal bloom (HAB)-forming dinoflagellate Karenia brevis has been associated with lethal and sublethal effects on zooplankton that may offer both direct and indirect support of bloom formation and maintenance. Reductions in copepod grazing on $K$. brevis have been attributed to acute physiological incapacitation and nutritional inadequacy. To evaluate the potential toxicity or nutritional inadequacy of $K$. brevis, food removal and egg production experiments were conducted using the copepod Acartia tonsa and K. brevis strains CCMP 2228, Wilson, and SP-1, characterized using liquid chromatography-mass spectrometry (LC-MS) as having high, low, and no brevetoxin levels, respectively. Variable grazing rates were found in experiments involving mixtures of toxic CCMP 2228 and Wilson strains. However, in experiments with toxic CCMP 2228 and non-toxic SP-1 strains, A. tonsa grazed SP-1 at significantly higher rates than the toxic alternative. Additionally, $A$. tonsa experienced significantly greater mortality when exposed to toxic $K$. brevis strains, particularly after prolonged exposure. Egg production rates of copepods fed toxic $K$. brevis strains were similar to those of starved copepods, while those of copepods fed non-toxic SP-1 and the nutritious Rhodomonas salina were significantly higher. Analysis indicates that $K$. brevis impacts grazer populations via multiple synergistic mechanisms: (1) decreased ingestion rates, (2) decreased egg production, and (3) increased mortality of copepods through a combination of toxicity and nutritional inadequacy.
\end{abstract}

KEY WORDS: Copepod grazing - Harmful algae - Toxic dinoflagellate Chemical deterrent · Karenia brevis · Brevetoxin Resale or republication not permitted without written consent of the publisher

\section{INTRODUCTION}

As the primary grazers of oceanic phytoplankton, zooplankton are known to often regulate phytoplankton populations and may exert a top-down control on the abundance and composition of phytoplankton communities (Watras 1985, Banse 1992, Granéli et al. 1993). Many phytoplankton species that form harmful algal blooms (HABs) have evolved chemical, physical, or morphological defenses such as toxins (Huntley et al. 1986, Ives 1987, Waggett et al. 2008), extracellular polymeric substances (EPS) (Liu \& Buskey 2000), or spines (Nielsen 1991) that make them less palatable to zooplankton grazers and thereby disrupt the stable state of food web dynamics (Irigoien et al. 2005). The release of HAB species from top-down, grazer-mediated control can lead to a positive feedback interaction supporting bloom formation and proliferation (Sunda et al. 2006 and references therein).

The toxic, red-tide-producing dinoflagellate Karenia brevis is commonly found in the Gulf of Mexico 
(GOM) and the United States South Atlantic Bight (US SAB) (Tester et al. 1993, Tester \& Steidinger 1997, Magana et al. 2003). Throughout the GOM, K. brevis is routinely present at low levels (Geesey \& Tester 1993); however, massive, nearly monospecific blooms of $K$. brevis form on an almost annual basis along the western Florida coast (Tester \& Steidinger 1997, Stumpf et al. 1998). These blooms occur at concentrations often exceeding $10^{5}$ cells $\mathrm{l}^{-1}$. They can cover areas 10 to $1000 \mathrm{~km}^{2}$ and may persist for months at a time (Steidinger \& Joyce 1973). K. brevis is typically an oceanic species existing at background concentrations $<1000$ cells $1^{-1}$ in offshore environments and has adapted to low nutrient, oligotrophic environments by efficiently utilizing all sources of nitrogen and phosphorous (Baden \& Mende 1979, Bronk et al. 2004, Vargo et al. 2008).

Karenia brevis produces a suite of cyclic polyether compounds known as brevetoxins (PbTx) (Shimizu et al. 1986, Baden et al. 2005). Brevetoxins are lipidsoluble, depolarizing agents that bind to and subsequently open voltage-sensitive sodium channels (VSSC) causing an uncontrolled influx of sodium ions into the cell (Poli et al. 1986, Trainer \& Baden 1999). Significant environmental and human health consequences have been linked to the actions of brevetoxins. In humans, consumption of brevetoxin-laden shellfish results in the disruption of normal neurological processes, causing the illness clinically described as neurotoxic shellfish poisoning (NSP). Symptoms include acute gastrointestinal distress and neurological disorders (Steidinger \& Baden 1984, Baden et al. 1995). Aerosolized brevetoxins are also responsible for triggering respiratory distress in humans and marine mammals, and through various routes of exposure, they are the cause of mass mortality events of fish, seabirds, and marine mammals (Gunter et al. 1948, Forrester et al. 1977, Flewelling et al. 2005).

Numerous brevetoxins have been isolated from natural bloom events and laboratory cultures. Of these brevetoxins, PbTx-1 and PbTx-2 are suspected to be the parent molecules of 13 other known brevetoxin derivatives and, as such, are the most potent of the characterized toxins (Roszell et al. 1990, Baden et al. 2005). PbTx-1, -2 , and -3 are the dominant toxins measured during Karenia brevis bloom events. PbTx-2 is the most abundant intra-cellular brevetoxin, and therefore dominates during bloom situations with viable $K$. brevis populations and in laboratory cultures during logarithmic growth (Roszell et al. 1990). PbTx-3, a likely derivative of PbTx-2, is the dominant extra-cellular brevetoxin observed during blooms and prevails during later phases of a bloom and in declining phases of culture growth as $K$. brevis cells lyse and degrade (Roszell et al. 1990, Pierce et al. 2008). Both intra- and extra-cellular brevetoxins contribute to the toxin accumulation in shellfish and are linked to negative human and environmental health effects (Roberts et al. 1979, Pierce et al. 2006). Each brevetoxin exhibits a unique set of activities, interacting differently with the VSSC to produce a specific toxicity.

Brevetoxins are not the only bioactive compounds produced by Karenia brevis. K. brevis also manufactures multiple brevetoxin antagonists known collectively as brevenals (Bourdelais et al. 2004, 2005, Baden et al. 2005). Brevenals are fused-ring polyether compounds, shorter than brevetoxins, that counteract the effects of brevetoxins (Bourdelais et al. 2004, Baden et al. 2005). A second potential antagonist, brevesin, has recently been characterized as an inhibitor of PbTx-3 binding to VSSC (Satake et al. 2009). In addition, recent evidence suggests that $K$. brevis produces hemolytic toxins, compounds that lyse red blood cells, which may contribute to the overall toxicity of bloom events (Neely \& Campbell 2006, Tatters et al. 2009).

Within the plankton community, Karenia brevis has been reported to have negative impacts on both algal competitors and grazers. Competition experiments have revealed that $K$. brevis may be capable of allelopathy, since interactions with live cells and cellular extracts suppress the growth of multiple phytoplankton species (Freeberg et al. 1979, Kubanek et al. 2005). Additionally, competition experiments have demonstrated that $K$. brevis is avoided by most grazers. Multiple copepod species have been found to discriminate against $K$. brevis based on their toxin content, and lower reproductive and ingestion rates have been found for copepods fed diets dominated by $K$. brevis (Huntley et al. 1986, Speekmann et al. 2006, Breier \& Buskey 2007).

Although brevetoxin has not been implicated as the causative agent in Karenia brevis allelopathy, it is possible that brevetoxin is responsible for deterring grazers. Conflicting evidence currently exists within the literature regarding the role of brevetoxins as grazing deterrents. While some research suggests that copepods avoid consuming $K$. brevis due to its nutritional inadequacy (Collumb \& Buskey 2004, Speekmann et al. 2006, Breier \& Buskey 2007), other reports offer support that toxins are the cause of this avoidance (Huntley et al. 1986, Cohen et al. 2007). Recent studies offer convincing evidence that $K$. brevis is a low quality food for copepods, particularly Acartia tonsa, one of the dominant 
zooplankters found within blooms of $K$. brevis (Lester et al. 2008).

The current research was undertaken to answer the following question: Do copepods avoid Karenia brevis because it is nutritionally inadequate or because brevetoxins exert lethal and/or sublethal effects on grazers? To address this question, the calanoid copepod Acartia tonsa was exposed to monoalgal and mixed algal diets of $K$. brevis strains differing in toxicity using the model framework of Jonásdóttir et al. (1998). Preliminary toxin analysis of several $K$. brevis strains identified $K$. brevis CCMP 2228 as a toxic strain possessing high levels of brevetoxins (PbTx-1, -2, -3) and therefore served as our 'suspect' diet. Control diets consisted of a less toxic $K$. brevis strain Wilson (producing low levels of brevetoxins), the non-toxic $K$. brevis strain SP-1 (no quantifiable levels of brevetoxins), and an alternative good food, Rhodomonas salina. All strains were screened for hemolytic activity and were negative for hemolysis of red blood cells. Because $K$. brevis strain SP-1 contained no detectable traces of brevetoxin and tested negative for hemolytic activity, it will be referred to as 'non-toxic' in relation to the following experiments. Food removal experiments were first conducted to assess the short-term $(24 \mathrm{~h})$ effects of $K$. brevis strains ranging from highly toxic (CCMP 2228) to non-toxic (SP-1) on survivorship and grazing of copepods. Follow-up egg production experiments allowed us to evaluate the potential toxic or nutritional effects of $K$. brevis on copepod populations over a $48 \mathrm{~h}$ period.

\section{MATERIALS AND METHODS}

\section{Experimental organisms}

Karenia brevis (C. C. Davis) G. Hansen \& Ø. Moestrup, 2000 strains 2228 (Provasoli-Guillard National Center for Culture of Marine Phytoplankton; CCMP), Wilson and SP-1 (isolated by S. Pargee and provided by E. Buskey, University of Texas Marine Science Institute, Port Aransas, TX, USA) were cultured in L1 media (Guillard \& Hargraves 1993) at a salinity of 36 and a temperature of $23^{\circ} \mathrm{C}$ under fluorescent lights with a $14 \mathrm{~h}$ light:10 h dark cycle and $102 \mu \mathrm{mol}$ quanta $\mathrm{m}^{-2} \mathrm{~s}^{-1}$ of photosynthetically active radiation (PAR). The cryptophyte Rhodomonas salina CCMP 1319 was maintained under the same conditions using f/2 media (Guillard \& Rhyther 1962). Cell densities and average cell diameters were monitored daily using a Beckman Multisizer 3 Coul- ter Counter interfaced with a PC running Multisizer 3 ver. 3.51 software. Experiments were run with cells harvested during the exponential phase of their growth cycle. Seawater for cultures and experiments was collected from waters offshore North Carolina, USA, recognized as Gulf Stream waters from physical properties.

The calanoid copepod Acartia tonsa Dana, 1849 was used as the model grazer in food removal and egg production experiments with monoalgal and mixed algal diets of Karenia brevis. On the day of experimental set-up, a $102 \mu \mathrm{m}$ mesh, $0.5 \mathrm{~m}$ diameter plankton net was suspended from the National Oceanic and Atmospheric Administration (NOAA) dock on Pivers Island, Beaufort, NC, USA $\left(34^{\circ} 41.8^{\prime} \mathrm{N}, 76^{\circ} 40.2^{\prime} \mathrm{W}\right)$ during an outgoing tide for up to $45 \mathrm{~min}$. Contents of the cod end were diluted with ambient seawater and returned to the laboratory. Adult copepods were isolated from the plankton under a dissecting microscope and thoroughly examined to ensure individuals appeared healthy and free of external parasites. Groups of 20 (food removal experiments) or 12 (egg production experiments) $A$. tonsa were held within individual $25 \mathrm{ml}$ plastic cups filled with $10 \mathrm{ml}$ sterile-filtered seawater (36) for $\sim 1 \mathrm{~h}$ until added to experimental bottles $(500 \mathrm{ml})$.

\section{Biochemical analyses}

Prior to each experiment, 3 subsamples of the selected diets (Karenia brevis strain(s) and/or Rhodomonas salina) were filtered through pre-combusted Pall Type A/E $13 \mathrm{~mm}$ filters and frozen for future analysis of particulate $\mathrm{C}$ and $\mathrm{N}$. The day before analysis, filters were fumed overnight with concentrated $\mathrm{HCl}$ to remove inorganic carbon. Filters were then dried for $1 \mathrm{~h}$ at $100^{\circ} \mathrm{C}$ and analyzed on a Costech Elemental Combustion System (ECS) 4010 interfaced with a PC running Elemental Analysis Software (EAS).

Brevetoxin analysis was performed using liquid chromatography-mass spectrometry (LC-MS). Liquid-liquid extractions of brevetoxins were performed on the date of the experiment by mixing $40 \mathrm{ml}$ of a Karenia brevis culture at a 1:1 ratio with ethyl acetate. The solution was sonicated with a Branson Sonifier 250 equipped with a microtip to disrupt the cells. Extraction was repeated 2 additional times, and the 3 resulting extracts were collected and combined. The extract was washed by adding an equivalent amount of Milli-Q water to desalt the solution. The ethyl acetate layer was then collected, and the vol- 
ume was reduced to dryness using a Yamato RE500 Rotary Evaporator and then redissolved in $0.5 \mathrm{ml}$ acetonitrile. Samples were then run on a LC1100 coupled to a Thermo Finnigan TSQ Quantum LC-MS system. The instrument was run in multiple-response monitor mode to identify and quantify brevetoxins $\mathrm{PbTx}-1, \mathrm{PbTx}-2$, and PbTx-3 in units of pg cell ${ }^{-1}$. The presence or absence of brevenal was also recorded; however, we were unable to obtain a brevenal standard at the time of the experiments to quantify the amount per cell.

\section{Food removal experiments}

Three sets of feeding experiments were conducted using different Karenia brevis prey mixtures, including CCMP 2228:Wilson at high and medium cell densities, and CCMP 2228:SP-1 at high cell densities. These classifications were based on the categorization scheme used by Florida Fish and Wildlife Conservation Commission Fish and Wildlife Research Institute (FWRI) where medium $K$. brevis concentrations range from $10^{5}$ to $10^{6}$ cells $\mathrm{l}^{-1}$ and high concentrations are $>10^{6}$ cells l$^{-1}$. In each experiment, copepods were exposed to 6 treatment diets: a 'no food' treatment and 5 monoalgal or mixed algal diets. Treatment bottles contained both $K$. brevis cells and 20 Acartia tonsa females, and control bottles contained $K$. brevis cells only. In the 'no food' treatment, A. tonsa adults were added to bottles containing only $0.22 \mu \mathrm{m}$ filtered seawater. Each experiment was run in triplicate with 3 bottles per treatment $(n=15$ treatment bottles) and control ( $\mathrm{n}=15$ control bottles). Monoalgal diets consisted of $K$. brevis cells from only one of the cultures (CCMP 2228, Wilson, or SP-1). Three mixed algal diets were created by adding cultures of $K$. brevis strains to $500 \mathrm{ml}$ polycarbonate bottles in ratios of $75 \%$ 2228:25\% Wilson, $50 \%$ 2228:50\% Wilson, and 25\% 2228:75\% Wilson for the CCMP 2228:Wilson experiments, or $75 \% 2228: 25 \%$ SP-1, $50 \%$ 2228:50\% SP-1, and 25\% 2228:75\% SP-1 for the CCMP 2228:SP-1 experiment. Contents of the bottles were then diluted with $0.22 \mu \mathrm{m}$ filtered seawater inoculated with L1 nutrients at a salinity of 36 to a density of $1.4 \times 10^{6}$ cells $^{-1}$ for CCMP 2228:Wil-

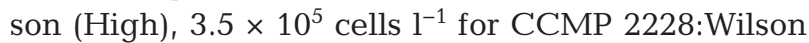
(Medium), and $1.35 \times 10^{6}$ cells $^{-1}$ for CCMP 2228:SP1 (High). All bottles were filled to a volume of $400 \mathrm{ml}$. Experimental bottles were then mixed via slow, gentle inversion several times, and $10 \mathrm{ml}$ subsamples were taken from each bottle to perform live cell counts using a Coulter Counter. Following sampling,
20 A. tonsa adult females were added to each of the 15 treatment bottles containing one of the diets and the 3 'no food' treatment bottles. Ten $\mathrm{ml} 0.22 \mu \mathrm{m}$ filtered seawater was added to each of the control bottles to maintain equivalent cell densities among treatment and control bottles. Experimental bottles were maintained at $23^{\circ} \mathrm{C}$ on a $14 \mathrm{~h}$ light: $10 \mathrm{~h}$ dark cycle with $102 \mu \mathrm{mol}$ quanta $\mathrm{m}^{-2} \mathrm{~s}^{-1}$ PAR for $17 \mathrm{~h}$.

Following this incubation period, experimental bottles were once again mixed via gentle inversion, and $10 \mathrm{ml}$ subsamples were taken from each bottle to perform live cell counts using a Coulter Counter as soon as the last sample had been collected. Subsamples were examined under a dissecting microscope, and, if present, copepods were removed with a pipette and placed in a petri dish with filtered seawater. Contents of treatment bottles were then gently poured over a $150 \mu \mathrm{m}$ mesh sieve to collect copepods. The bottle was rinsed 3 times to collect any remaining Acartia tonsa on the sieve, and the retained copepods were gently rinsed into the appropriate petri dish. Total surviving and dead copepods were enumerated under a dissecting microscope. Clearance and ingestion rates were calculated using the equations of Frost (1972). Results are reported in terms of both clearance rates, $F$, and ingestion rates, $I$, which are the product of clearance rates and the average cell concentration in the treatment bottle.

\section{Egg production experiments}

To assess the quality of Karenia brevis monoalgal and mixed algal diets, 3 egg production experiments were performed using the following prey mixtures: CCMP 2228:Wilson, CCMP 2228:SP-1, and CCMP 2228: Rhodomonas salina. In the $2 \mathrm{~K}$. brevis prey mixture experiments (CCMP 2228:Wilson and CCMP 2228:SP-1), the same experimental design as the food removal experiments was used, with copepods exposed to 6 treatment diets; however, in all egg production experiments only 12 adult Acartia tonsa (10 female, 2 male) were used per treatment bottle. Once again, experiments were run in triplicate, and the same monoalgal and mixed algal diet ratios were used as treatments. The cryptophyte $R$. salina is a known nutritious dietary choice when rearing copepods. Therefore, the egg production experiment involving toxic $K$. brevis CCMP 2228 and $R$. salina served as a control experiment to assess the maximum egg and fecal pellet production of the local wild population of $A$. tonsa. In this experiment, only 4 treatment diets were used: a 'no food' treatment, 2 
monoalgal diets consisting of either $100 \%$ K. brevis CCMP 2228 or $100 \%$ R. salina, and a $50 \%$ K. brevis CCMP 2228:50\% R. salina mixed algal diet. In all 3 egg production experiments, contents of the treatment bottles were diluted with $0.22 \mu \mathrm{m}$ filtered seawater inoculated with L1 nutrients to $\sim 1.5 \mathrm{mg} \mathrm{C} \mathrm{l}^{-1}$ $\left(\sim 2.0 \times 10^{6}\right.$ cells $1^{-1}$ for $K$. brevis strains and $\sim 1.1 \times 10^{8}$ cells $1^{-1}$ for $R$. salina). The calculated average carbon concentrations of the $K$. brevis strains were similar: SP-1: $0.738 \mathrm{ng} \mathrm{cell}^{-1}$, Wilson: $0.795 \mathrm{ng}$ cell $^{-1}, \mathrm{CCMP}$ 2228: $0.790 \mathrm{ng} \mathrm{cell}^{-1}$ while $R$. salina had a calculated carbon content of only $0.033 \mathrm{ng}$ cell $^{-1}$. Ten ml subsamples were collected from gently mixed experimental bottles (final volume, $400 \mathrm{ml}$ ) prior to adding copepods. Subsamples were used to perform live cell counts using a Coulter Counter. After adding copepods and seawater, experimental bottles were incubated at $23^{\circ} \mathrm{C}$ on a $14 \mathrm{~h}$ light:10 h dark cycle with $102 \mu \mathrm{mol}$ quanta $\mathrm{m}^{-2} \mathrm{~s}^{-1}$ PAR for $24 \mathrm{~h}$.

After $24 \mathrm{~h}$, a $10 \mathrm{ml}$ subsample was taken from each bottle for cell counts via the Coulter Counter. Contents of the experimental bottles were then filtered through nested 153 and $40 \mu \mathrm{m}$ mesh sieves. Copepods were retained on the $153 \mu \mathrm{m}$ mesh sieve, rinsed into a Petri dish, and examined under a dissecting microscope. The survivorship of the copepods was assessed and all remaining live copepods were returned to their original bottle. Eggs and fecal pellets were captured by the $40 \mu \mathrm{m}$ sieve and discarded. After $48 \mathrm{~h}$, contents of the bottles were again filtered through nested 153 and $40 \mu \mathrm{m}$ mesh sieves, and a $10 \mathrm{ml}$ subsample was taken from each bottle for live cell counts with the Coulter Counter. Copepods were counted under a dissecting microscope and mortality assessed. Eggs and fecal pellets retained on the $40 \mu \mathrm{m}$ mesh were rinsed into $25 \mathrm{ml}$ scintillation vials with $0.22 \mu \mathrm{m}$ filtered seawater at a salinity of 36 . Collected eggs and fecal pellets were preserved with $1 \%$ acid Lugol's iodine $24 \mathrm{~h}$ after collection to allow nauplii to hatch and counted within 1 wk. Grazing rates were calculated as described in 'Food removal experiments'.

\section{Statistical analysis}

Student's $t$-test was used to compare the carbon:nitrogen ratios of Karenia brevis strains and Rhodomonas salina during the food removal and egg production experiments.
Normality and equal variance tests were run on measured survival, clearance, and ingestion rates of Acartia tonsa as well as their egg and fecal pellet production rates. Data passing these tests were analyzed using 1-way factorial analysis of variance (ANOVA) and post hoc Tukey's honestly significant differences (HSD) tests for multiple comparisons.

\section{RESULTS}

\section{Biochemical analyses}

Elemental analysis of the strains revealed a high degree of variability among the strains and between the experiments; however, all strains were nitrogen replete and contained $>1$ mole $\mathrm{N}^{-1}$. During one food removal experiment (CCMP 2228:Wilson [Medium]) and 2 egg production experiments (CCMP 2228:Wilson and CCMP 2228:SP-1), no significant differences were found in the $\mathrm{C}: \mathrm{N}$ ratios of the Karenia brevis strains used (Table 1). In the remaining experiments, $\mathrm{C}: \mathrm{N}$ ratios of the diets were significantly different. $\mathrm{C}: \mathrm{N}$ ratios ranged from $3.3 \pm 0.7$ (mean $\pm \mathrm{SD}, \mathrm{n}=3$ ) to $7.4 \pm 0.2$ among the experiments (Table 1).

Brevetoxin analysis was performed using LC-MS and results confirmed that toxin content varied both among and within the strains. Karenia brevis CCMP 2228 was determined to be highly toxic with levels of $\mathrm{PbTx}-2$ ranging from $11.67 \pm 2.28$ to $73.20 \mathrm{pg} \mathrm{PbTx}-2$ cell $^{-1}$ during food removal and egg production experiments (Table 2). PbTx-1 and PbTx-3 were also present in CCMP 2228 during all experiments, but in lower quantities. The $K$. brevis Wilson strain had much lower levels of PbTx-2 and PbTx-3 than CCMP

Table 1. Karenia brevis and Rhodomonas salina. Summary of the carbon:nitrogen ratios of $K$. brevis strains (CCMP 2228, Wilson and SP-1) during the 2228:Wilson, 2228:SP-1, and 2228:R. salina food removal and egg production experiments. C:N ratios represent mean (SD); $\mathrm{n}=3$ for each experiment and strain. Probability values (p) calculated using Student's $t$-test where $\mathrm{n}=3$ and $\mathrm{df}=4$. Bold values are significant at the $\alpha<0.05$ level

\begin{tabular}{|lcccccccc|}
\hline \multirow{2}{*}{ Experiment } & \multirow{2}{*}{ Strain } & \multicolumn{3}{c}{ Food removal } & \multicolumn{3}{c|}{ Egg production } \\
& & C:N & $t$ & $\mathrm{p}$ & $\mathrm{C}: \mathrm{N}$ & $t$ & $\mathrm{p}$ \\
\hline 2228:Wilson & 2228 & $5.2(0.3)$ & 0.94 & 0.402 & & & \\
(Medium) & Wilson & $5.0(0.2)$ & & & & & \\
2228:Wilson & 2228 & $\mathbf{5 . 3 ( 0 . 2 )}$ & $\mathbf{- 6 . 1 0}$ & $\mathbf{0 . 0 0 4}$ & $4.2(0.3)$ & -2.14 & 0.100 \\
(High) & Wilson & $\mathbf{6 . 5 ( 0 . 3 )}$ & & & $5.3(0.8)$ & & \\
2228:SP-1 & 2228 & $\mathbf{7 . 4 ( 0 . 2 )}$ & $\mathbf{5 . 5 4}$ & $\mathbf{0 . 0 0 5}$ & $3.9(0.3)$ & 1.71 & 0.163 \\
& SP-1 & $\mathbf{5 . 9 ( 0 . 4 )}$ & & & $3.3(0.7)$ & & \\
2228:R. salina & 2228 & & & & $\mathbf{7 . 2 ( 0 . 1 )}$ & $\mathbf{2 9 . 2 8}$ & $<\mathbf{0 . 0 0 1}$ \\
& R. salina & & & & $\mathbf{5 . 1 ( 0 . 1 )}$ & & \\
\hline
\end{tabular}


Table 2. Karenia brevis. Summary of the toxin content of $K$. brevis strains during the 2228:Wilson and 2228:SP-1 food removal and egg production experiments. Values represent mean (SD) $n=3$ except the 2228:Wilson (High) food removal experiment where $n=1$. NQ: non-quantifiable $;-$ : no toxins detected; +: present, yet not quantified; NA: not applicable

\begin{tabular}{|lccccc|}
\hline $\begin{array}{l}\text { Experiment type } \\
\text { Diet }\end{array}$ & Strain & $\begin{array}{c}\text { PbTx-1 } \\
\left(\text { pg cell }^{-1}\right)\end{array}$ & $\begin{array}{c}\text { PbTx-2 } \\
\left(\text { pg cell }^{-1}\right)\end{array}$ & $\begin{array}{c}\text { PbTx-3 } \\
\left(\text { pg cell }^{-1}\right)\end{array}$ & Brevenal \\
\hline $\begin{array}{l}\text { Food removal } \\
\text { 2228:Wilson (High) }\end{array}$ & 2228 & 9.28 & 73.20 & 6.78 & + \\
& Wilson & NQ & 3.67 & 0.24 & + \\
2228:SP-1 & 2228 & $0.62(0.05)$ & $35.71(2.20)$ & $1.60(0.19)$ & NA \\
& SP-1 & - & - & - & NA \\
Egg production & & & & & \\
2228:Wilson (High) & 2228 & $1.76(0.33)$ & $11.67(2.28)$ & $0.12(0.03)$ & + \\
& Wilson & $0.11(0.13)$ & $1.27(0.82)$ & $0.01(0.01)$ & + \\
2228:SP-1 & 2228 & $1.51(0.10)$ & $13.15(1.55)$ & $0.11(0.02)$ & + \\
& SP-1 & NQ & NQ & - & - \\
\hline
\end{tabular}

2228 during the CCMP 2228:Wilson (High) food removal experiment and lower but detectable levels of PbTx-1, -2 and -3 during the egg production experiment (Table 2). Brevetoxins were not detected in strain SP-1 during the food removal experiment; however, low, yet non-quantifiable levels of PbTx-1 and PbTx-2 were present during the egg production experiment (Table 2). A peak for the antagonist compound brevenal was also present during analysis of $K$. brevis strains CCMP 2228 and Wilson with particularly broad peaks in the Wilson strain and CCMP 2228 during the egg production experiment. The concentration of the compound could not be determined due to the unavailability of a brevenal standard.

\section{Food removal experiments}

In the CCMP 2228:Wilson food removal experiments (High and Medium), no significant differences were found in the survivorship of Acartia tonsa among treatments regardless of toxicity (Fig. 1A,B; ANOVA, $F_{5}=1.84,2.68, \mathrm{p}=0.179,0.075$, respectively). Significant differences in A. tonsa survivorship were found during the CCMP 2228:SP-1 food removal experiment (Fig. $1 C_{i}$ ANOVA, $F_{5}=6.56, p=$ 0.0037). Significantly lower survivorship was found in the $100 \% 2228$ treatment, averaging only $90.2 \pm$ $2.2 \%$.

Grazing rates appeared to be affected by the toxicity of the diet. In the CCMP 2228:Wilson (High and Medium) experiments, Acartia tonsa had significantly different clearance rates among the treatments (Fig. 2A,B; ANOVA, $F_{4}=5.63,4.17, \mathrm{p}=0.012$,
0.031, respectively). High variability was found in the CCMP 2228:Wilson (High) experiment with negative clearance rates for the $75 \% 2228: 25 \%$ Wilson and 25\% 2228:75\% Wilson treatments; however, comparable clearance rates were calculated for the highly toxic $100 \% 2228$ and lower toxicity $100 \%$ Wilson treatments (Fig. 2A). In the CCMP 2228:Wilson (Medium) experiment, negative clearance rates of $-0.46 \pm 0.12 \mathrm{ml}$ ind. ${ }^{-1} \mathrm{~h}^{-1}$ were calculated for copepods exposed to the highly toxic $100 \% 2228$ treatment (Fig. 2B). Pairwise comparisons indicate that this was significantly lower than clearance rates on the $25 \% 2228: 75 \%$ Wilson treatment, the treatment with the highest clearance rates of $0.55 \pm 0.41 \mathrm{ml}$ ind..$^{-1} \mathrm{~h}^{-1}$. The effects of toxins on copepod grazing rates were more pronounced during the CCMP 2228:SP-1 food removal experiment. A. tonsa clearance rates were significantly different among the treatments (Fig. $2 \mathrm{C}_{\mathrm{i}}$ ANOVA, $F_{4}=16.98, \mathrm{p}=0.0002$ ), and positive grazing rates were observed only for diets dominated by the non-toxic strain SP-1. Positive clearance rates of 0.10 \pm 0.16 and $0.49 \pm 0.01 \mathrm{ml}$ ind.$^{-1} \mathrm{~h}^{-1}$ were measured for the $25 \% 2228: 75 \%$ SP-1and 100\% SP-1 treatments, respectively. Pairwise comparisons show that clearance rates on the $100 \%$ SP-1 treatment were significantly higher than for all other treatments.

Similar patterns were observed for calculated ingestion rates (prey number and carbon-based) during the food removal experiments. In the CCMP 2228:Wilson (High) experiment, negative ingestion rates were observed in the $75 \% 2228: 25 \%$ Wilson and $25 \% 2228: 75 \%$ Wilson treatments, while high ingestion rates of $541.7 \pm 265.4$ cells ind. ${ }^{-1} \mathrm{~h}^{-1}$ or $319.2 \pm 156.4 \mathrm{ng} \mathrm{C}$ ind. ${ }^{-1} \mathrm{~h}^{-1}$ were measured for the $100 \% 2228$ treatment (Fig. 3A,D; ANOVA, $F_{4}=5.78$, $6.8, \mathrm{p}=0.011,0.007$, respectively). In the CCMP 2228:Wilson (Medium) experiment, negative ingestion rates were measured for the highly toxic $100 \%$ 2228 treatment. Differences among the treatments were only marginally significant on a prey number basis (Fig. 3B; ANOVA, $F_{4}=3.36, p=0.055$ ), but were more strongly significant on a carbon basis (Fig. 3E; ANOVA, $\left.F_{4}=4.37, \mathrm{p}=0.027\right)$. Ingestion rates in all other treatments were positive and were highest in the $25 \% 2228: 75 \%$ Wilson treatment (Fig. 3B, E; $282.2 \pm 266.7$ prey ind..$^{-1} \mathrm{~h}^{-1}$ or $220.3 \pm 208.1 \mathrm{ng} \mathrm{C}$ ind..$^{-1} \mathrm{~h}^{-1}$ ). 


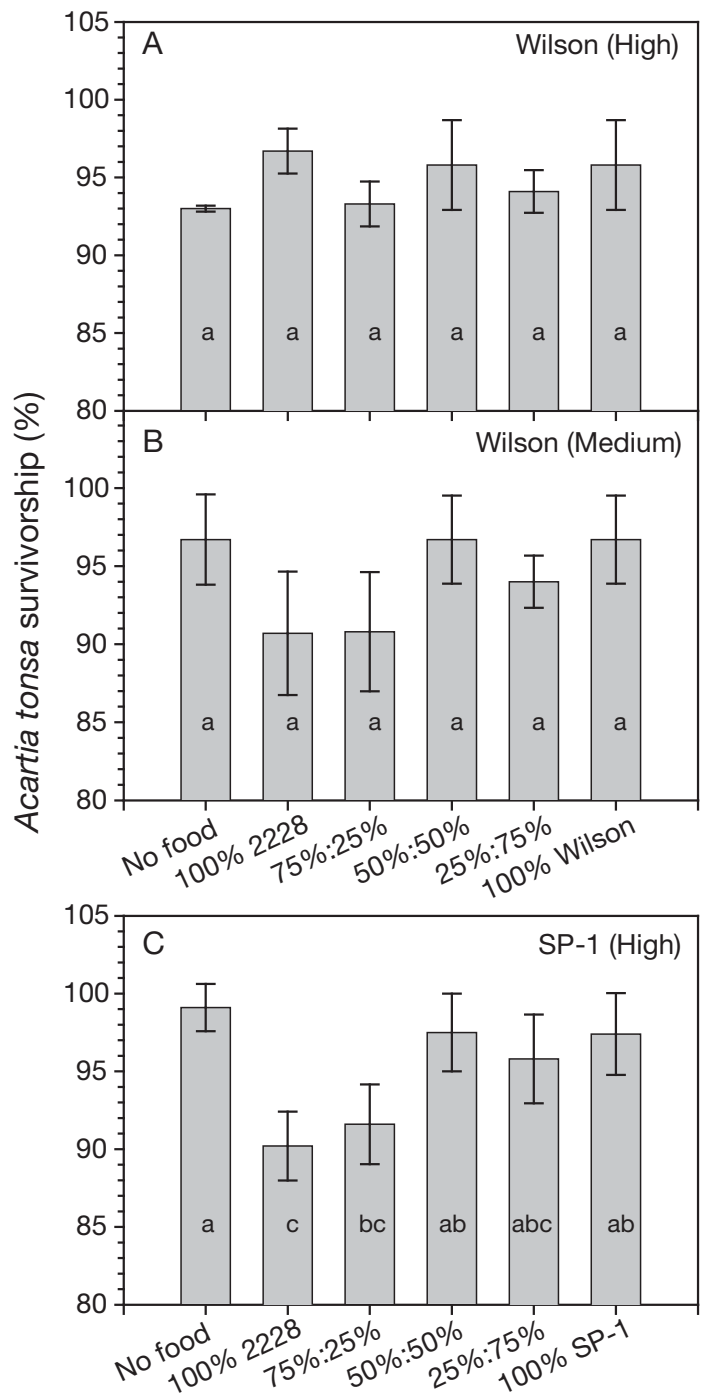

Fig. 1. Acartia tonsa and Karenia brevis. Mean survivorship (\%) of A. tonsa following food removal experiments from $K$. brevis (A) 2228:Wilson (High), (B) 2228:Wilson (Medium), and (C) 2228:SP-1 (High) food removal experiments. $75 \%: 25 \%, 50 \%: 50 \%, 25 \%: 75 \%$ on the $x$-axis: first value is CCMP 2228; second value is (A,B) Wilson or (C) SP-1. Error bars indicate $\pm 1 \mathrm{SD}$. Different letters $(\mathrm{a}, \mathrm{b}, \mathrm{c})$ on the bars indicate significant differences among treatments according to post-hoc Tukey's honestly significant difference (HSD), $\mathrm{p}<0.05$

Acartia tonsa ingestion rates were also significantly different among treatments within the CCMP 2228:SP-1 experiment. Significantly higher ingestion rates were observed on the non-toxic $100 \%$ SP-1 treatment than on the toxic $100 \% 2228,75 \%$ 2228:25\% SP-1, and 50\% 2228:50\% SP-1 treatments (Fig. 3C,F; ANOVA, $F_{4}=8.52,7.52, \mathrm{p}=0.0029$, 0.0046 , respectively). Positive ingestion rates of 111.6 \pm 182.0 prey ind. ${ }^{-1} \mathrm{~h}^{-1}\left(64.8 \pm 105.7 \mathrm{ng} \mathrm{C}\right.$ ind..$\left.^{-1} \mathrm{~h}^{-1}\right)$ and $381.5 \pm 16.7$ prey ind. ${ }^{-1} \mathrm{~h}^{-1}(209.7 \pm 9.2 \mathrm{ng} \mathrm{C}$

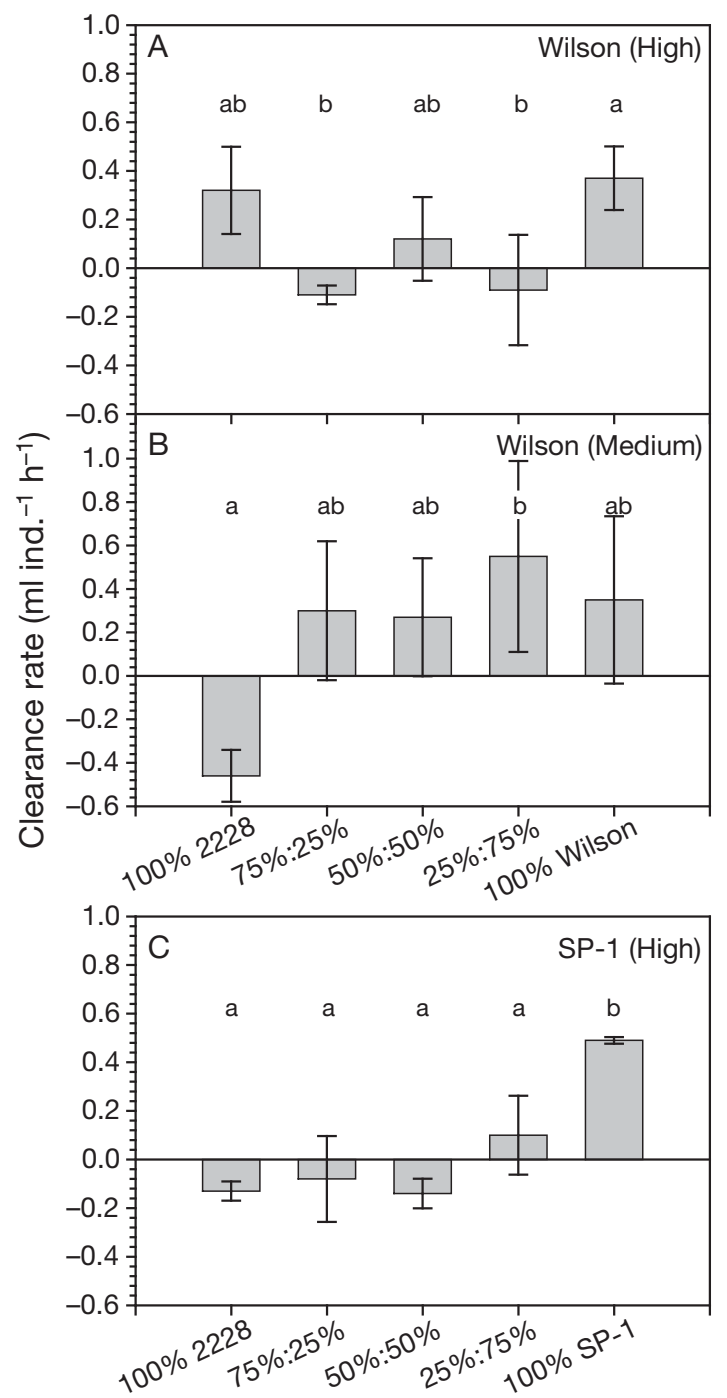

Fig. 2. Acartia tonsa and Karenia brevis. Mean clearance rates (ml ind.$^{-1} \mathrm{~h}^{-1}$ ) of $A$. tonsa on monoalgal and mixed algal diets of $K$. brevis during (A) 2228:Wilson (High), (B) 2228:Wilson (Medium), and (C) 2228:SP-1 (High) food removal experiments. See Fig. 1 for further details

ind. $^{-1} \mathrm{~h}^{-1}$ ) were measured for the $25 \% 2228: 75 \%$ SP-1 and $100 \%$ SP-1 treatments, respectively.

\section{Egg production experiments}

In the control egg production experiment with Karenia brevis CCMP 2228:Rhodomonas salina, copepods survived equally well in all treatments after $24 \mathrm{~h}$ (Fig. 4A; ANOVA, $F_{3}=0.24, \mathrm{p}=0.866$ ); however, significant differences in Acartia tonsa survivorship were found after $48 \mathrm{~h}$ of exposure, with the greatest survival $(94.2 \pm 0.7 \%)$ in the $100 \% R$. salina 

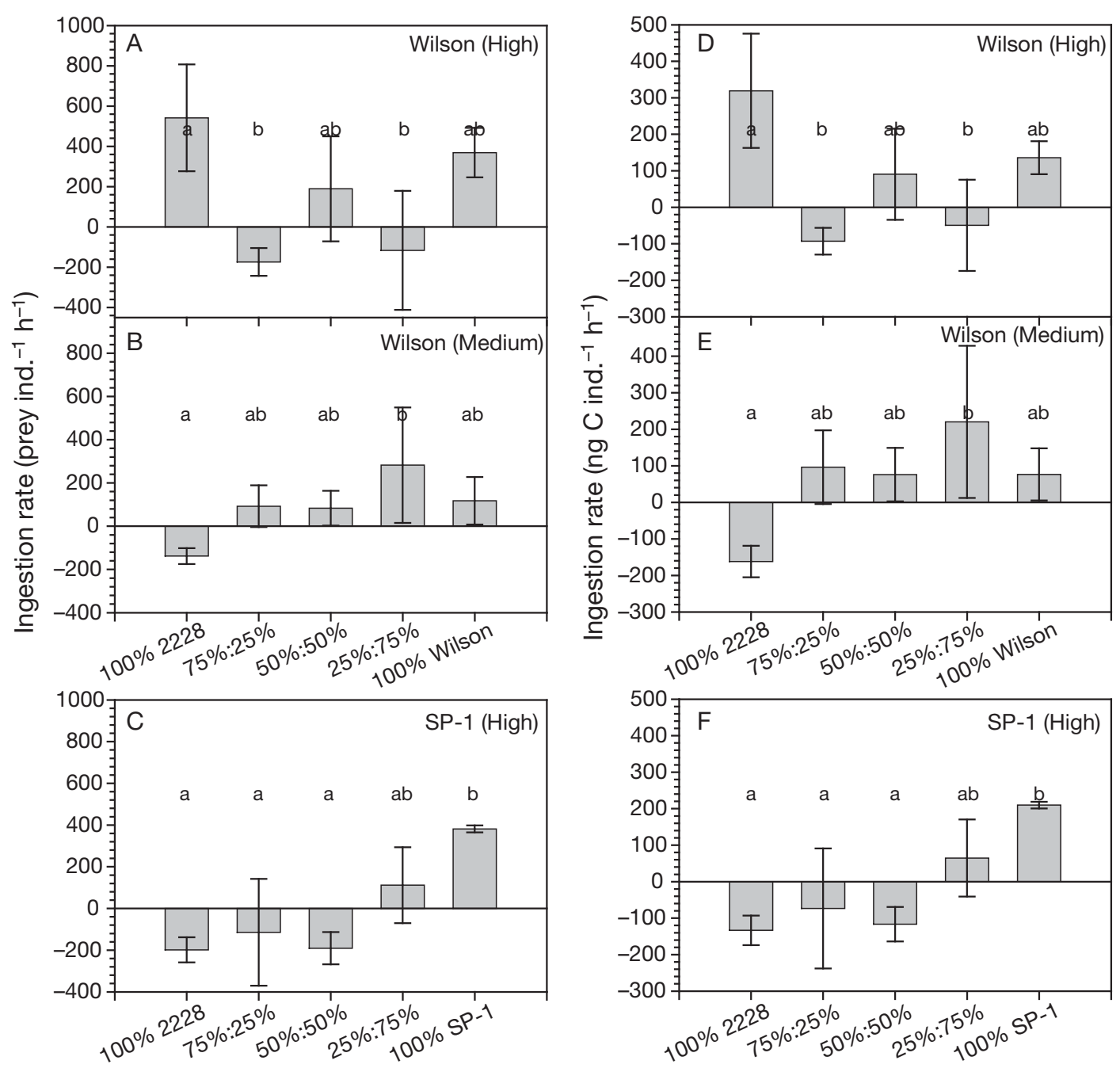

Fig. 3. Acartia tonsa and Karenia brevis. Mean ingestion rates (prey ind. ${ }^{-1} \mathrm{~h}^{-1}$ and $\mathrm{ng} \mathrm{C}_{\text {ind. }}{ }^{-1} \mathrm{~h}^{-1}$ ) of $A$. tonsa on monoalgal and mixed algal diets of $K$. brevis during (A,D) 2228:Wilson (High), (B,E) 2228:Wilson (Medium), and (C,F) 2228:SP-1 (High) food removal experiments. $75 \%: 25 \%, 50 \%: 50 \%, 25 \%: 75 \%$ on the $x$-axis: first value is CCMP 2228; second value is (A,B,D,E) Wilson or $(\mathrm{C}, \mathrm{F}) \mathrm{SP}-1$. See Fig. 1 for further details

treatment and the lowest $(66.6 \pm 4.8 \%)$ in the $100 \%$ K. brevis CCMP 2228 treatment (Fig. 4B; ANOVA, $F_{3}$ $=6.63, \mathrm{p}=0.015$ ). Although no significant differences in copepod survival were found among treatments in the CCMP 2228:Wilson egg production experiment (Fig. $4 \mathrm{C}, \mathrm{D} ;$ ANOVA, $F_{5}=1.01,0.83, \mathrm{p}=0.451,0.552$, respectively), there was a notable decline in copepod survival in all treatments from a mean of $87.8 \pm 9.1 \%$ after $24 \mathrm{~h}$ to $73.5 \pm 12.9 \%$ after an additional $24 \mathrm{~h}$. After a $24 \mathrm{~h}$ exposure to the diets in the CCMP 2228:SP-1 experiment, no significant differences were apparent in copepod survival (Fig. 4E; ANOVA, $F_{5}=2.01, \mathrm{p}=0.148$ ); however, $A$. tonsa survival from 24 to $48 \mathrm{~h}$ was significantly different among treatments (Fig. $4 \mathrm{~F}_{\text {; }}$ ANOVA, $F_{5}=10.22, \mathrm{p}<0.001$ ). Low- est survivorship was found in the $100 \% 2228$ (65.0 \pm $8.7 \%)$ and the $75 \% 2228: 25 \%$ SP-1 $(72.2 \pm 6.9 \%)$ treatments. Pairwise comparisons indicate significantly higher survival of over $90 \%$ in the 'no food', $25 \% 2228: 75 \%$ SP-1, and $100 \%$ SP-1 treatments (Fig. 4F).

Copepods in the Karenia brevis CCMP 2228: Rhodomonas salina control experiment had positive and significantly higher rates of clearance and algal ingestion (both prey and carbon based) of $R$. salina in the $100 \% R$. salina treatment (Fig. 5A-C; ANOVA, $\mathrm{p}=0.031,0.005,0.006$, respectively). Positive grazing rates on $R$. salina were also measured in the $50 \%$ $2228: 50 \%$ R. salina treatment, but this was not significantly different than grazing rates on CCMP 2228 

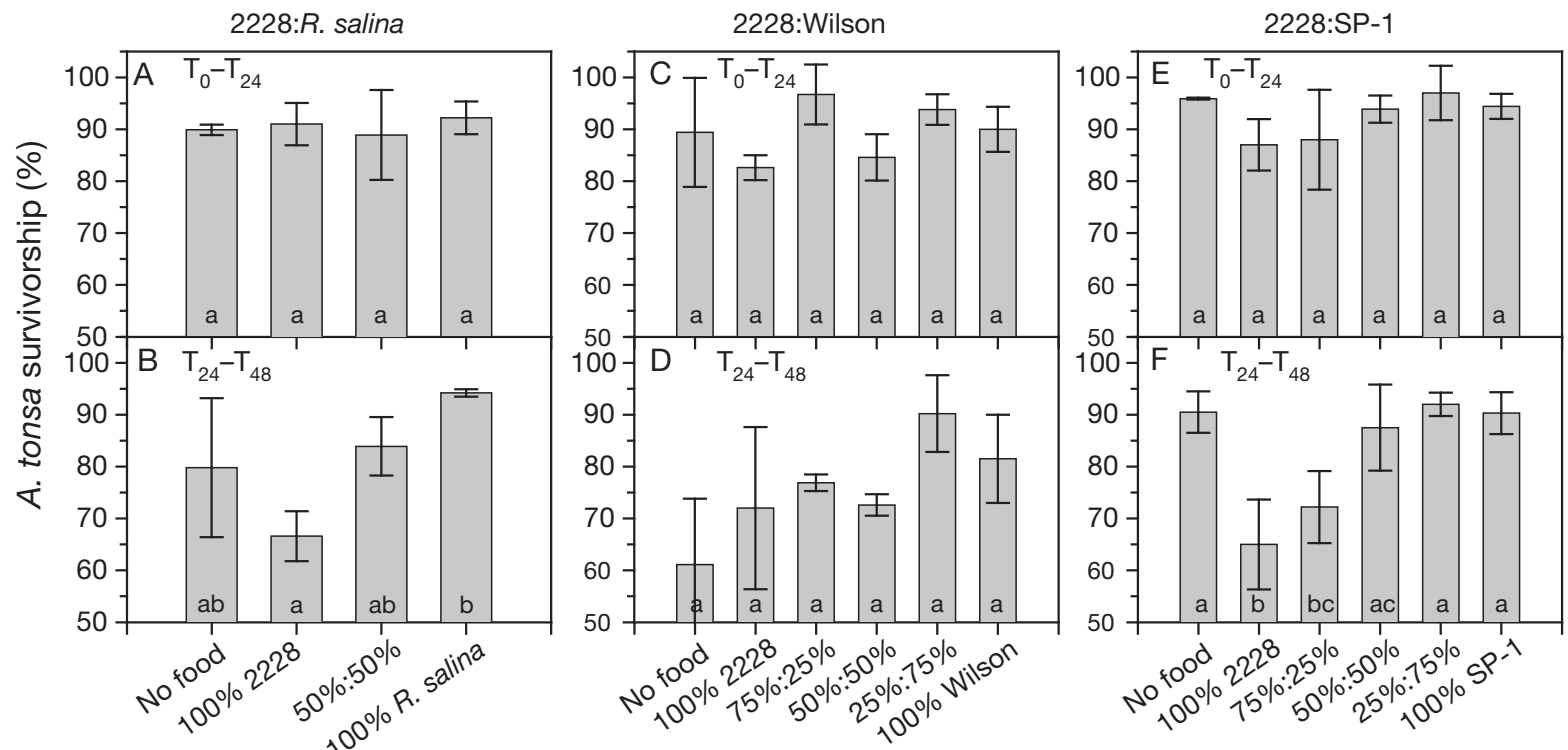

Fig. 4. Acartia tonsa, Karenia brevis and Rhodomonas salina. Mean survivorship (\%) of A. tonsa exposed to monoalgal and mixed algal diets of $K$. brevis CCMP 2228 and (A,B) $R$. salina, (C,D) K. brevis Wilson, and (E,F) K. brevis SP-1 during egg production experiments. Exposure time (T) was (A,C,E) 0 to $24 \mathrm{~h}$ or $(\mathrm{B}, \mathrm{D}, \mathrm{F}) 24$ to $48 \mathrm{~h} .75 \%: 25 \%, 50 \%: 50 \%, 25 \%: 75 \%$ on the

$x$-axis: first value is CCMP 2228; second value is $(A, B)$,$R . salina, (C, D)$ Wilson, or $(E, F)$ SP-1. See Fig. 1 for further details
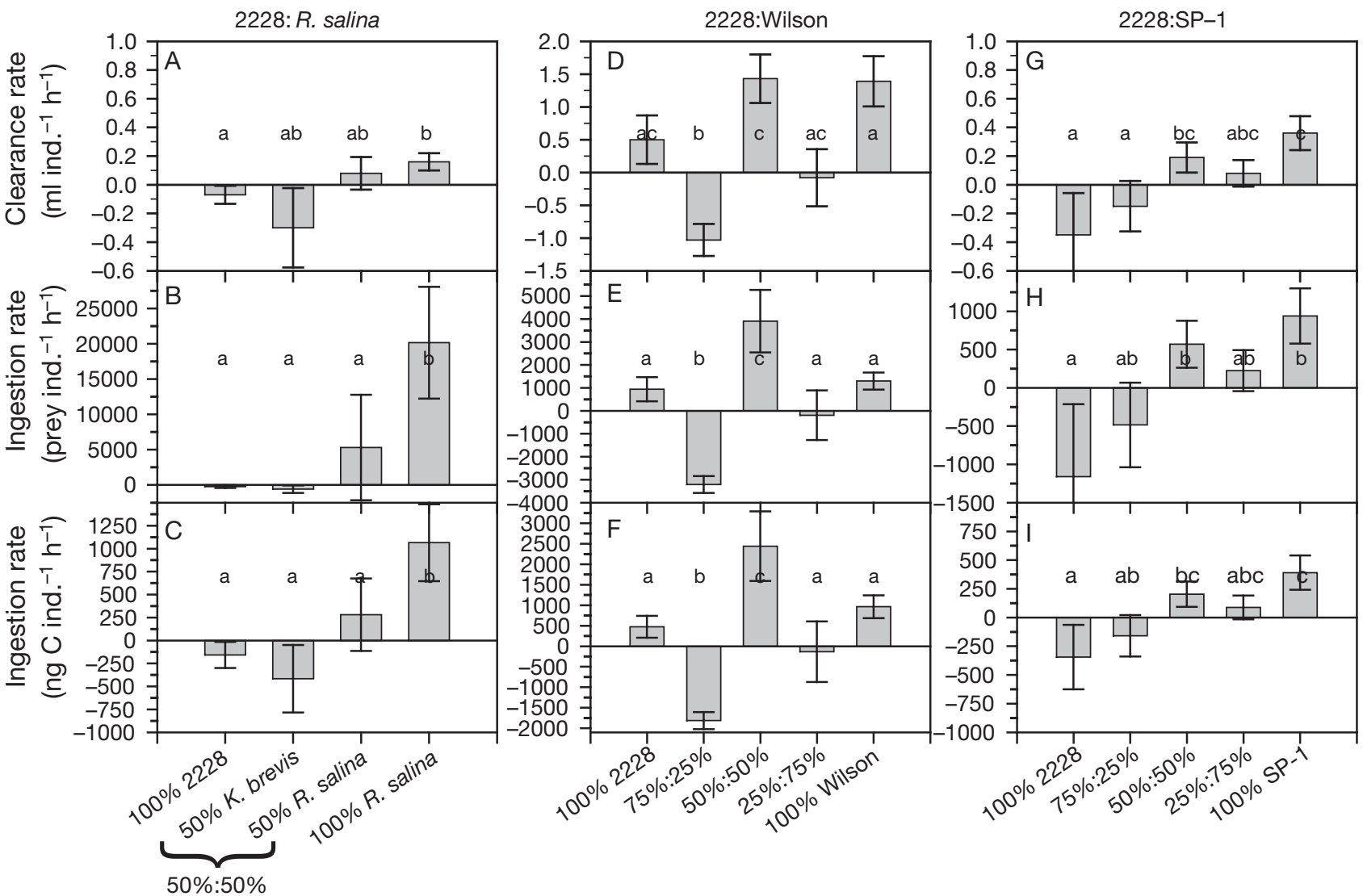

Fig. 5. Acartia tonsa, Karenia brevis and Rhodomonas salina. Grazing rates of A. tonsa during K. brevis CCMP 2228 and (A,C) R. salina, (D-F) K. brevis Wilson, and (G-I) K. brevis SP-1 egg production experiments reported as $(\mathrm{A}, \mathrm{D}, \mathrm{G})$ mean clearance rates $\left(\mathrm{ml}\right.$ ind..$\left.^{-1} \mathrm{~h}^{-1}\right),(\mathrm{B}, \mathrm{E}, \mathrm{H})$ mean ingestion rates (prey ind.$\left.^{-1} \mathrm{~h}^{-1}\right)$, and $(\mathrm{C}, \mathrm{F}, \mathrm{I})$ mean ingestion rates (ng $\mathrm{C}$ ind. $\left.{ }^{-1} \mathrm{~h}^{-1}\right) . \mathrm{Note}$ differences in the $y$-axis scaling among the experiments. $75 \%: 25 \%, 50 \%: 50 \%, 25 \%: 75 \%$ on the $x$-axis: first value is CCMP 2228 ; second value is (D-F) Wilson or (G-I) SP-1. See Fig. 1 for further details 

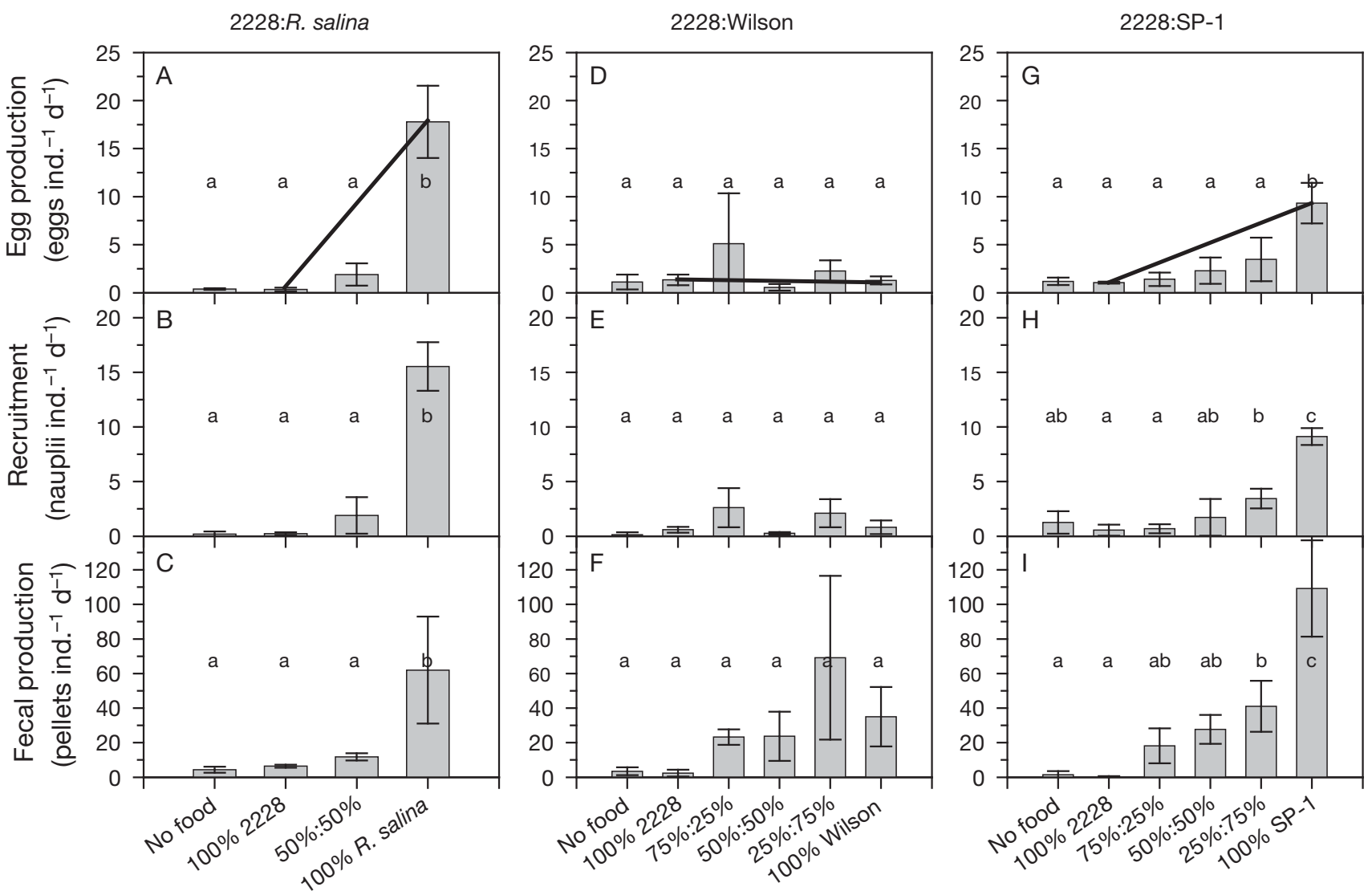

Fig. 6. Acartia tonsa, Karenia brevis and Rhodomonas salina. Offspring and fecal pellet production. (A,D,G) Egg production (eggs ind..$\left.^{-1} \mathrm{~d}^{-1}\right),(\mathrm{B}, \mathrm{E}, \mathrm{H})$ recruitment (nauplii ind..$\left.^{-1} \mathrm{~d}^{-1}\right)$, and $(\mathrm{C}, \mathrm{F}, \mathrm{I})$ fecal pellet production (pellets ind. ${ }^{-1} \mathrm{~d}^{-1}$ ) of $A$. tonsa during $K$. brevis CCMP 2228 and (A-C) R. salina, (D-F) K. brevis Wilson, and (G-I) K. brevis SP-1 egg production experiments. Black line in $(A, D, G)$ represents reference line connecting production at 100\% suspect and 100\% control diets. $75 \%: 25 \%$, $50 \%: 50 \%, 25 \%: 75 \%$ on the $x$-axis: first value is CCMP 2228 ; second value is (A,C) $R$. salina, (D-F) Wilson, or (G-I) SP-1.

See Fig. 1 for further details

(Fig. 5A-C). Acartia tonsa consumed an average of $20146.9 \pm 7918.5 R$. salina ind $^{-1} \mathrm{~h}^{-1}(1065.4 \pm$ $418.8 \mathrm{ng} \mathrm{C}$ ind..$^{-1} \mathrm{~h}^{-1}$ ).

Similar to the variation measured in the CCMP 2228:Wilson high cell density food removal experiment, a high degree of variability in Acartia tonsa grazing rates was observed among treatments in the CCMP 2228:Wilson egg production experiment (Fig. 5D-F). Positive clearance and ingestion rates (prey- and carbon-based) were measured for the $100 \% 2228,50 \% 2228: 50 \%$ Wilson, and 100\% Wilson treatments. Significantly higher ingestion rates of $3908 \pm 1360.9$ Karenia brevis ind ${ }^{-1} \mathrm{~h}^{-1}(2441.7 \pm$ $850.1 \mathrm{ng} \mathrm{C}$ ind. ${ }^{-1} \mathrm{~h}^{-1}$ ) were measured for the $50 \%$ 2228:50\% Wilson treatment (Fig. 5B, C; ANOVA, $F_{4}=$ 28.02, 24.85, p < 0.001, 0.001, respectively).

Acartia tonsa clearance and ingestion (prey- and carbon-based) rates were significantly different among treatments within the CCMP 2228:SP-1 egg production experiment (Fig. 5G-I; ANOVA, $F_{4}=$ $7.80,7.11,8.12, p=0.004,0.006,0.004$, respectively). Positive grazing rates were measured only for the $50 \% \quad 2228: 50 \% \quad$ SP-1, $25 \% \quad 2228: 75 \% \quad$ SP-1, and $100 \%$ SP-1 treatments. Highest clearance and ingestion rates were observed in the $100 \%$ SP-1 treatment with copepods consuming $939.1 \pm 359.9$ Karenia brevis ind. ${ }^{-1} \mathrm{~h}^{-1}\left(390.9 \pm 149.8 \mathrm{ng} \mathrm{C}\right.$ ind. $\left.{ }^{-1} \mathrm{~h}^{-1}\right)$.

In the control egg production experiment with Karenia brevis CCMP 2228:Rhodomonas salina, copepods produced significantly more eggs $(17.8 \pm$ 3.8 eggs ind. ${ }^{-1} \mathrm{~d}^{-1}$ ) when exposed to the $100 \% R$. salina diet than all other treatments (Fig. 6A; ANOVA, $\left.F_{3}=55.78, \mathrm{p}<0.001\right)$. Additionally, the $100 \% R$. salina diet supported a significantly greater number of nauplii $\left(15.5 \pm 2.2\right.$ nauplii ind.$^{-1} \mathrm{~d}^{-1}$; Fig. $6 \mathrm{~B} ;$ ANOVA, $\left.F_{3}=84.92, \mathrm{p}<0.001\right)$ and fecal pellet production $\left(62.0 \pm 31.0\right.$ fecal pellets ind.$^{-1} \mathrm{~d}^{-1}$; Fig. $6 \mathrm{C}$ ANOVA, $\left.F_{3}=9.34, \mathrm{p}=0.005\right)$. In contrast, very 
few eggs or nauplii were produced during the CCMP 2228:Wilson experiment (Fig. 6D,E). No significant differences in egg production rates (Fig. 6D; ANOVA, $F_{5}=1.63, p=0.225$ ) were found among the treatments. Recruitment ranged from $0.1 \pm 0.2$ to 2.6 \pm 1.8 nauplii ind.$^{-1} \mathrm{~d}^{-1}$ and was significantly different among treatments, with greatest numbers found in the $75 \% 2228: 25 \%$ Wilson and 25\% 2228:75\% Wilson treatments (Fig. 6E; ANOVA, $F_{5}=3.48, \mathrm{p}=$ 0.036). Fecal pellet production varied significantly among treatments (Fig. 6F; $F_{5}=3.93$, ANOVA, $\mathrm{p}=$ $0.024)$, with greatest production in the $25 \%$ 2228:75\% Wilson treatment $(69.1 \pm 47.4$ fecal pellets ind. ${ }^{-1} \mathrm{~d}^{-1}$ ) and lowest rates in the 'no food' and $100 \%$ 2228 treatments $(3.5 \pm 2.3$ and $2.4 \pm 2.0$ fecal pellets ind. ${ }^{-1} \mathrm{~d}^{-1}$, respectively).

In the CCMP 2228:SP-1 experiment, significant differences were found among treatments for egg production, recruitment, and fecal pellet production (Fig. 6G-I). Copepods exposed to the 100\% SP-1 diet produced significantly more eggs $(9.3 \pm 2.1$ eggs ind. $\left.^{-1} \mathrm{~d}^{-1}\right)$ and more nauplii $\left(9.1 \pm 0.8\right.$ nauplii ind. $^{-1}$ $\mathrm{d}^{-1}$ ) than in all other treatments (Fig. 6G, $\mathrm{H}_{;}$ANOVA, $F_{5}=14.98,33.56$, respectively, $\mathrm{p}<0.001$ for each). Additionally, copepods produced significantly more fecal pellets in the $100 \%$ SP-1 treatment (109.2 \pm 27.9 fecal pellets ind.$^{-1} \mathrm{~d}^{-1}$ ) when compared with all other treatments, and more fecal pellets in the $25 \%$ $2228: 75 \%$ SP-1 treatment $(41.1 \pm 14.7$ fecal pellets ind. ${ }^{-1} \mathrm{~d}^{-1}$ ) than in the 'no food' and $100 \% 2228$ treatments (Fig. 6I; ANOVA, $F_{5}=25.14, \mathrm{p}<0.001$ ). In the CCMP 2228:Rhodomonas salina and CCMP 2228:SP-1 experiments, low egg production rates for mixed diet treatments indicate that CCMP 2228 is either a toxic prey or that Acartia tonsa actively selects against CCMP 2228 (Fig. 6A,G). Similarities in egg production rates in the CCMP 2228:Wilson experiment indicate that CCMP 2228 and Wilson strains offer equally poor nutrition or toxicity to Acartia tonsa (Fig. 6D).

\section{DISCUSSION}

\section{Is Karenia brevis toxic to copepod grazers or merely nutritionally inadequate?}

Both toxicity and nutritionally inadequate food reduce the grazing and egg production rates of Acartia tonsa when fed toxic Karenia brevis. Three lines of evidence support the role of toxicity in compromising grazing rates of $A$. tonsa. First, copepod survivorship was significantly reduced after exposure to the highly toxic K. brevis CCMP 2228 for more than $24 \mathrm{~h}$. This was particularly apparent during experiments involving a non-toxic alternative food (Rhodomonas salina or SP-1). In these experiments, copepods had a higher survival rate when starved than when exposed to $100 \%$ CCMP 2228. Second, grazing rates on all prey were significantly suppressed in treatments dominated by toxic CCMP 2228 (Figs. 2 \& 4). Finally, copepods exposed to toxic strains of $K$. brevis (CCMP 2228 and Wilson) exhibited severe reductions in both egg and fecal pellet production. In addition, egg production on the non-toxic $K$. brevis strain SP-1 was only half of that on a nutritionally adequate food source, R. salina (Fig. 6).

\section{Toxic effects of Karenia brevis}

The conclusions above were made, in part, by applying the experimental approach provided by Jónasdóttir et al. (1998), wherein we were able to examine whether Karenia brevis is beneficial, nutritionally poor, or toxic to Acartia tonsa. Jónasdóttir et al.'s model requires that grazers be offered monoalgal and mixed algal diets of suspect and nutritionally sufficient prey, as done in the current study using the brevetoxin-laden $K$. brevis CCMP 2228 as our suspect food. In egg production experiments using the non-toxic, nutritionally replete, Rhodomonas salina as the control food, results showed that $K$. brevis CCMP 2228 was truly toxic to exposed copepods. Not only was egg production depressed relative to what would be expected for a nutritionally insufficient food (Fig. 6A), but low ingestion rates (Fig. 5A-C) and high mortality (Fig. 4B) all indicate toxic effects of $K$. brevis CCMP 2228 exposure.

Analysis of the egg production experiments using the non-toxic Karenia brevis SP-1 and low toxicity $K$. brevis Wilson as the control food provides additional insight into the inimical effects of $K$. brevis CCMP 2228. Given adequate concentrations of nutritionally sufficient food, egg production rates of Acartia tonsa typically range from 20 to 60 eggs female $^{-1} \mathrm{~d}^{-1}$ (Jónasdóttir 1994, Kleppel et al. 1998, Hazzard \& Kleppel 2003). Egg production rates on a diet of SP-1 are only half of those measured on the nutritional food, Rhodomonas salina, suggesting that brevetoxins are not the only factor limiting reproductive output. If $K$. brevis SP-1 was a nutritious food source, we would expect egg production rates similar to those on $R$. salina. When SP-1 dominated the prey field ( $25 \%$ 2228:75\% SP-1), prey switching most likely occurred, as indicated by the 
increased survivorship (Fig. 5F), positive ingestion rates (Fig. 5G-I), and higher egg and fecal pellet production (Fig. 6G-I); however, if CCMP 2228 is $>50 \%$ of the prey field, toxic effects result in mortality and decreased ingestion. Copepods had higher clearance rates on SP-1 than on $R$. salina; however, due to different cell concentrations and carbon content in the prey, this amounted to lower carbon-based ingestion rates on SP-1 vs. $R$. salina. Interestingly, copepods fed $100 \% R$. salina ingested 2.7 times the carbon of copepods fed $100 \%$ SP-1. This may potentially contribute to the reduced egg production rates of copepods in the SP-1 diet. Results of the egg production experiment involving the 2 toxic $K$. brevis strains, CCMP 2228 and Wilson, clearly indicated that the 2 diets were equivalent food items and neither was nutritionally sufficient to support egg production. Despite variable, yet sometimes high grazing rates, egg production and fecal pellet production on diets of toxic $K$. brevis remained low and similar to those of starved copepods (Fig. 6D-F).

\section{Nutritional quality of Karenia brevis}

While the C:N ratios from these experiments indicate that all strains of Karenia brevis were nitrogen-replete, the source of nutritional inadequacy likely stems from the inability of $K$. brevis to produce sterols essential for copepod growth and reproduction. Cholesterol is the dominant sterol found in copepod tissues and make up 89 to $99 \%$ of the total sterol composition in wild and lab-reared populations of Acartia tonsa (Goad 1981, Ederington et al. 1995). Reductions in copepod egg production result from a lack of dietary sterols, thus supporting the current assumption that copepods are incapable of de novo synthesis of membrane sterols and must rely on dietary sources to sustain development (Goad 1981, Ederington et al. 1995, Crockett \& Hassett 2005). Giner et al. 2003 and Mooney et al. 2007 determined that $K$. brevis produces large quantities of rare, unsaturated sterols which are likely to be non-nutritious for zooplankton grazers due to their unusual structure. Further, $K$. brevis lacks the 27-methyl group necessary for their sterols to be converted into cholesterol, the dominant sterol in calanoid copepods. This offers further evidence that even non-toxic strains of $K$. brevis would be insufficient to nutritionally support lasting copepod production during a bloom event (Giner et al. 2003).

\section{Grazing on Karenia brevis}

Results of other researchers have indicated varying responses of copepods to Karenia brevis exposure. Turner \& Tester (1989) found that during a rare bloom event off the North Carolina coast, the cooccurring copepod species Acartia tonsa, Oncaea venusta, and Labidocera aestiva all consumed $K$. brevis at rates increasing with cell concentration, while Centropages typicus and Paracalanus quasimodo ceased grazing; however, in prey selection experiments, A. tonsa, L. aestiva, and C. typicus all selected against $K$. brevis in favor of consuming Skeletonema costatum. Prey selection results do favor the conclusion that $K$. brevis is either toxic or not a sufficient food for grazers, a fact supported by our results and many other studies (Collumb \& Buskey 2004, Speekmann et al. 2006, Breier \& Buskey 2007). Low to negligible grazing rates on monoalgal diets of $K$. brevis have been documented repeatedly for A. tonsa populations from the GOM (Collumb \& Buskey 2004, Speekmann et al. 2006, Breier \& Buskey 2007). These low grazing rates were coupled with reduced egg production rates similar to starved copepods, further supporting the conclusion that $K$. brevis is not a nutritionally viable food source, or is toxic. Cohen et al. (2007) examined the effects of $K$. brevis and brevetoxins on populations of $A$. tonsa, C. typicus, and Temora turbinata from inshore North Carolina waters. Variable grazing rates were measured with low mortality upon exposure to either $K$. brevis cells or brevetoxins, yet significant sublethal behavioral effects were observed for C. typicus and T. turbinata, attributable to a combined effect of starvation and $K$. brevis toxicity.

Several reasons may explain the disparity among the results of previous grazing experiments. First, the biogeographic source of the experimental copepod population may factor into the observed responses. Experiments using copepod populations from the western GOM repeatedly show no significant mortality, yet show low egg production and grazing rates on monoalgal diets of Karenia brevis, with high grazing on mixtures of $K$. brevis and a nutritious algal species (Collumb \& Buskey 2004, Speekmann et al. 2006, Breier \& Buskey 2007). These populations experience more frequent exposure to $K$. brevis blooms than counterparts from the US SAB. Although $K$. brevis does extend into US SAB waters, only one documented bloom has been reported offshore North Carolina where copepods were collected for the current experiment and those done by Turner \& Tester (1998) and Cohen et al. (2007). In the GOM, long-term 
exposure to $K$. brevis may have selected for a population of Acartia tonsa more resistant to brevetoxins. Genetic subpopulations of $A$. tonsa have been identified in the GOM and along the US Atlantic coast (Caudill \& Bucklin 2004, Chen \& Hare 2008). Resistance to the toxic dinoflagellate Alexandrium fundyense has been documented for historically exposed populations of the congeneric copepod Acartia hudsonica from Maine and has been induced in naïve populations from the waters off New Jersey (Colin \& Dam 2004, Avery \& Dam 2007). Given this information, it is highly likely that $A$. tonsa populations in the GOM may be better evolved to tolerate toxic $K$. brevis than those in the US SAB. However, the present study indicates that $K$. brevis has evolved 2 effective strategies to deter grazers: toxin production and a nutritional state that does not support reproductive efforts of co-occurring copepod grazers. These 2 tactics may work synergistically to deter multiple grazers and promote the formation and maintenance of monospecific bloom events.

\section{Variability in toxin content}

Variability in Karenia brevis populations may also affect observed results during predator-prey experiments. Toxin levels of $K$. brevis vary among and within strains depending on culture conditions and growth phase (Baden \& Tomas 1988, Roszell et al. 1990, Loret et al. 2002). In the present experiments, we measured the brevetoxin content of cells on the day of experimentation. Our results showed variability in toxin content both within and among strains, most probably due to culture growth conditions. Of the 3 strains used during the experiments, CCMP 2228 was the most toxic; however, PbTx-2 concentrations varied by 6 -fold over the experiments. Levels of $\mathrm{PbTx}-2$ varied by almost 3 -fold within the Wilson strain. Fluctuations in toxin production have been reported previously for $K$. brevis (Baden \& Tomas 1988, Roszell et al. 1990, Loret et al. 2002) and other phytoplankton species (Johansson \& Granéli 1999a,b, Adolf et al. 2009). Shifts in both brevetoxin congeners and total toxin content have been documented for $K$. brevis over different growth phases (Baden \& Tomas 1988, Roszell et al. 1990). Additionally, Loret et al. (2002) reported significantly different toxin contents for 5 strains of $K$. brevis cultured under identical conditions and significant toxin levels $\left(12.23+0.02 \mathrm{pg} \mathrm{PbTx}-2 \mathrm{cell}^{-1}\right)$ were found in strain SP-1, which has proven to be non-toxic during the present study.
Toxic Karenia brevis strains (CCMP 2228 and Wilson) also produced detectable levels of the brevetoxin antagonist brevenal. Although, the brevenal concentrations were not quantified, it is interesting to note the apparent absence of brevenal in the nontoxic strain SP-1. The implication here is that perhaps brevenal serves as a self-protective compound for $K$. brevis, and concentrations may vary along with the potency of brevetoxins being produced. It will be important in future work to quantify brevenal concentrations to determine if this is a mediating factor counteracting the lethal and sublethal effects of brevetoxins on grazers.

It is imperative that grazing and production experiments involving toxic phytoplankton also include concurrent toxin analysis since toxins vary with culture condition, growth phase, nutrient availability, and between strains (Baden \& Tomas 1988, Roszell et al. 1990, Loret et al. 2002, present study). Also, toxin potency varies with presence/absence of antagonists such as brevenal and gambieric acid, which could have direct consequences on the behavior and mortality of grazers. The results described here indicate that care should be taken before assumptions regarding an entire species are made based on results of experiments using a single strain under a single set of culture conditions.

\section{Karenia brevis disrupts top-down grazer control}

The results of the present study indicate that Karenia brevis has evolved mechanisms to reduce grazing pressure and alter food web dynamics. Further, $K$. brevis fits the 3 criteria necessary to be classified as an ecosystem disruptive algal bloom (EDAB) species (Sunda et al. 2006). First, it is widely known that $K$. brevis forms massive, nearly monospecific blooms on an almost annual basis in the GOM West Florida Shelf. Second, results presented here and by other researchers indicate that zooplankton exhibit decreased grazing and reproductive rates due to both the toxic and nutritional state of $K$. brevis. The third condition required by the EDAB model is the formation of feedbacks, as evidenced by the reduction in grazing, increased copepod mortality, decreased egg production, and potential changes in copepod behavior when exposed to toxic $K$. brevis diets. These factors suggest that zooplanktonmediated nutrient recycling would be interrupted, thereby reducing nutrient concentrations and favoring the proliferation of a low nutrient-adapted species such as $K$. brevis. As witnessed by field observa- 
tions, these blooms often persist for weeks or months at a time. $K$. brevis may act as an EDAB species via both reduced grazing and nutrient recycling (Mechanism 1), or increased toxin production under nutrient limitation (Mechanism 2) (Sunda et al. 2006), which has been shown to occur in other toxic dinoflagellates including the haptophytes Chrysochromulina polylepis and Prymnesium parvum (Johansson \& Granéli 1999a,b) and the 'brown tide' alga Aureococcus anophagefferens (Bricelj et al. 2001).

These adaptive mechanisms could favor the development of an EDAB during each stage of the bloom event (Steidinger \& Vargo 1988, Steidinger et al. 1998). During the initiation stage of a bloom, Karenia brevis is introduced to an area, yet exists at background concentrations. Given the results presented here and by previous researchers, copepods and other herbivores should continue to graze on the available phytoplankton community, selecting for nutritional, non-toxic food sources over $K$. brevis (Turner \& Tester 1998, Collumb \& Buskey 2004, Speekmann et al. 2006). Since copepods would be selectively eliminating algal competitors of $K$. brevis, this should facilitate the transition to the growth stage of the bloom allowing k-selected, low-nutrientadapted $K$. brevis populations to grow to a state of dominance. As the bloom evolves, nutrient limitation increases with decreasing rates of grazing and grazer-linked nutrient recycling, and $K$. brevis comes to dominate, which further reduces grazing rates. This inherent positive feedback mechanism should promote further bloom proliferation and maintenance-Stage 3 of the bloom. As seen in the present study, exposure to toxic $K$. brevis strains leads to increased copepod mortality, reduced ingestion rates, and reduced egg production. These combined effects should further contribute to declining grazer populations, the release of $K$. brevis populations from top-down control, and a subsequent reduction in nutrient recycling thus favoring $\mathrm{k}$-selected species such as $K$. brevis. These positive feedback mechanisms will continue to maintain the $K$. brevis bloom until some physical mechanisms such as a change in wind or currents act to disperse the bloom, leading to the final bloom stage of termination. However, if grazing is completely eliminated and recycling completely stops, the $K$. brevis will deplete local nutrients and cells may senesce from apoptosis or necrosis.

Acknowledgements. We are grateful to E. J. Buskey of The University of Texas, Marine Science Institute for generously providing cultures of Karenia brevis strain SP-1; W. G. Sunda and R. W. Litaker for their critical review of the manuscript; and the insights of 3 anonymous reviewers. Funding for R.J.W. was provided through a National Research Council RAP postdoctoral research associateship funded by the CCFHR, NOS, NOAA.

\section{LITERATURE CITED}

> Adolf JE, Bachvaroff TR, Place AR (2009) Environmental modulation of karlotoxin levels in strains of the cosmopolitan dinoflagellate, Karlodinium veneficum (Dinophyceae). J Phycol 45:176-192

Avery DE, Dam HG (2007) Newly discovered reproductive phenotypes of a marine copepod reveal costs and advantages of resistance to a toxic dinoflagellate. Limnol Oceanogr 52:2099-2108

- Baden DG, Mende TJ (1979) Amino acid utilization by Gymnodinium breve. Phytochemistry 18:247-251

Baden DG, Tomas CR (1988) Variations in major toxin composition for 6 clones of Ptychodiscus brevis. Toxicon 26: 961-963

Baden DG, Fleming LE, Bean JA (1995) Marine toxins. In: DeWolf FA (ed) Handbook of clinical neurology: intoxications of the nervous system. Part H. Natural toxins and drugs. Elsevier, Amsterdam, p 141-175

Baden DG, Bourdelais AJ, Jacocks H, Michelliza S, Naar J (2005) Natural and derivative brevetoxins: historical background, multiplicity, and effects. Environ Health Perspect 113:621-625

Banse K (1992) Grazing, temporal changes of phytoplankton concentrations, and the microbial loop in the open sea. In: Falkowski P, Woodhead AD (eds) Primary productivity and biogeochemical cycles in the sea. Plenum Press, New York, NY, p 409-440

> Bourdelais AJ, Campbell S, Jacocks H, Naar J, Wright JLC, Carsi J, Baden DG (2004) Brevenal is a natural inhibitor of brevetoxin action in sodium channel receptor binding assays. Cell Mol Neurobiol 24:553-563

Bourdelais AJ, Jacocks HM, Wright JLC, Bigwarfe PM Jr, Baden DG (2005) A new polyether ladder compound produced by the dinoflagellate Karenia brevis. J Nat Prod 68:2-6

> Breier CF, Buskey EJ (2007) Effects of the red tide dinoflagellate, Karenia brevis, on grazing and fecundity in the copepod Acartia tonsa. J Plankton Res 29:115-126

- Bricelj VM, MacQuarrie SP, Schaffner RA (2001) Differential effects of Aureococcus anophagefferens isolates ('brown tide') in unialgal and mixed suspensions on bivalve feeding. Mar Biol 139:605-615

Bronk DA, Sanderson MP, Mulholland MR, Heil CA, O'Neil JM (2004) Organic and inorganic nitrogen uptake kinetics in field populations dominated by Karenia brevis. In: Steidinger KA, Landsberg $\mathrm{JH}$, Tomas CR, Vargo GA (eds) Harmful algae 2002. Florida Fish and Wildlife Conservation Commission, Florida Institute of Oceanography, and Intergovernmental Oceanographic Commission of UNESCO, St. Petersburg, FL, p 80-82

> Caudill CC, Bucklin A (2004) Molecular phylogeography and evolutionary history of the estuarine copepod, Acartia tonsa, on the Northwest Atlantic coast. Hydrobiologia 511:91-102

> Chen G, Hare MP (2008) Cryptic ecological diversification of a planktonic estuarine copepod, Acartia tonsa. Mol Ecol 17:1451-1468

> Cohen JH, Tester PA, Forward RB Jr. (2007) Sublethal 
effects of the toxic dinoflagellate Karenia brevis on marine copepod behavior. J Plankton Res 29:301-315

Colin SP, Dam HJ (2004) Testing for resistance of pelagic marine copepods to a toxic dinoflagellate. Evol Ecol 18: 355-377

Collumb CJ, Buskey EJ (2004) Effects of the toxic red tide dinoflagellate (Karenia brevis) on survival, fecal pellet production and fecundity of the copepod Acartia tonsa. In: Steidinger KA, Landsberg JH, Tomas CR, Vargo GA (eds) Harmful algae 2002. Florida Fish and Wildlife Conservation Commission, Florida Institute of Oceanography, and Intergovernmental Oceanographic Commission of UNESCO, St. Petersburg, FL, p 44-46

Crockett EL, Hassett RP (2005) A cholesterol-enriched diet enhances egg production and egg viability without altering cholesterol content of biological membranes in the copepod Acartia hudsonica. Physiol Biochem Zool 78: 424-433

Ederington MC, McManus GB, Harvey HR (1995) Trophic transfer of fatty-acids, sterols, and a triterpenoid alcohol between bacteria, a ciliate, and the copepod Acartia tonsa. Limnol Oceanogr 40:860-867

> Flewelling LJ, Naar JP, Abbott JP, Baden DG and others (2005) Red tides and marine mammal mortalities. Nature 435:755-756

Forrester DJ, Gaskin JM, White FH, Thompson NP and others (1977) An epizootic of waterfowl associated with a red tide episode in Florida. J Wildl Dis 13:160-167

Freeberg LR, Marshall A, Heyl M (1979) Interrelationships of Gymnodinium breve (Florida red tide) within the phytoplankton community. In: Taylor DL, Seliger $\mathrm{HH}$ (eds) Toxic dinoflagellate blooms. Elsevier, New York, NY, p 138-144

Frost BW (1972) Effects of size and concentration of food particles on the feeding behavior of the marine planktonic copepod Calanus pacificus. Limnol Oceanogr 17: 805-815

Geesey M, Tester PA (1993). Gymnodinium breve: ubiquitous in Gulf of Mexico waters? In: Smayda TJ Shimizu Y (eds) Toxic phytoplankton blooms. Elsevier, Amsterdam, p 251-255

Giner JL, Faraldos JA, Boyer GL (2003) Novel sterols of the toxic dinoflagellate Karenia brevis (Dinophyceae): a defensive function for unusual marine sterols? J Phycol 39:315-319

> Goad LJ (1981) Sterol biosynthesis and metabolism in marine invertebrates. Pure Appl Chem 53:837-852

> Granéli E, Olsson P, Carlsson P, Granéli W, Nylander C (1993) Weak 'top-down' control of dinoflagellate growth in the coastal Skagerrak. J Plankton Res 15:213-237

> Guillard RRL, Hargraves PE (1993) Stichochrysis immobilis is a diatom, not a chrysophyte. Phycologia 32:234-236

> Guillard RRL, Ryther JH (1962) Studies of marine planktonic diatoms. I. Cyclotella nana Hustedt and Detonula confervacea Cleve. Can J Microbiol 8:229-239

> Gunter G, Williams RH, Davis CC, Walton Smith FG (1948) Catastrophic mass mortality of marine animals and coincident phytoplankton bloom on the west coast of Florida, November 1946 to August 1947. Ecol Monogr 18: 309-324

> Hazzard SE, Kleppel GS (2003) Egg production of the copepod Acartia tonsa in Florida Bay: role of fatty acids in the nutritional composition of the food environment. Mar Ecol Prog Ser 252:199-206

- Huntley M, Sykes P, Rohan S, Marin V (1986) Chemically mediated rejection of dinoflagellate prey by the copepods Calanus pacificus and Paracalanus parvus: mechanism, occurrence and significance. Mar Ecol Prog Ser 28: $105-120$

> Irigoien X, Flynn KJ, Harris RP (2005) Phytoplankton blooms: a 'loophole' in microzooplankton grazing impact? J Plankton Res 27:313-321

Ives JD (1987) Possible mechanisms underlying copepod grazing responses to levels of toxicity in red tide dinoflagellates. J Exp Mar Biol Ecol 112:131-145

Johansson N, Granéli E (1999) Cell density, chemical composition and toxicity of Chrysochromulina polylepis (Haptophyta) in relation to different N:P supply ratios. Mar Biol 135:209-217

> Johansson N, Granéli E (1999b) Influence of different nutrient conditions on cell density, chemical composition and toxicity of Prymnesium parvum (Haptophyta) in semicontinuous cultures. J Exp Mar Biol Ecol 239:243-258

Jónasdóttir SH (1994) Effects of food quality on the reproductive success of Acartia tonsa and Acartia hudsonica: laboratory observations. Mar Biol 121:67-81

> Jónasdóttir SH, Kiørboe T, Tang KW, St John M, Visser AW, Saiz E, Dam HG (1998) Role of diatoms in copepod production: good, harmless or toxic? Mar Ecol Prog Ser 172: 305-308

Kleppel GS, Burkart CA, Houchin L (1998) Nutrition and the regulation of egg production in the calanoid copepod Acartia tonsa. Limnol Oceanogr 43:1000-1007

Kubanek JM, Hicks K, Naar J, Villareal TA (2005) Does the red tide dinoflagellate Karenia brevis use allelopathy to outcompete other phytoplankton? Limnol Oceanogr 50: 883-895

> Lester KM, Heil CA, Neely MB, Spence DN and others (2008) Zooplankton and Karenia brevis in the Gulf of Mexico. Cont Shelf Res 28:99-111

Liu H, Buskey EJ (2000) The exopolymer secretions (EPS) layer surrouding Aureoumbra lagunensis cells affects growth, grazing, and behavior of protozoa. Limnol Oceanogr 45:1187-1191

> Loret P, Tengs T, Villareal TA, Singler H and others (2002) No difference found in ribosomal DNA sequences from physiologically diverse clones of Karenia brevis (Dinophyceae) from the Gulf of Mexico. J Plankton Res 24: 735-739

Magańa HA, Contreras C, Villareal TA (2003) A historical assessment of Karenia brevis in the western Gulf of Mexico. Harm Algae 2:163-171

> Mooney BD, Nichols PD, de Salas MF, Hallegraeff GM (2007) Lipid, fatty acid, and sterol composition of eight species of Kareniaceae (Dinophyta): chemotaxomony and putative lipid phycotoxins. J Phycol 43:101-111

> Neely T, Campbell L (2006) A modified assay to determine hemolytic toxin variability among Karenia clones isolated from the Gulf of Mexico. Harm Algae 5:592-598

> Nielsen TG (1991) Contribution of zooplankton grazing to the decline of a Ceratium bloom. Limnol Oceanogr 36: 1091-1106

Pierce RH, Henry MS, Blum PC, Plakas SM and others (2006) Comparison of methods for determination of brevetoxins and their metabolites in NSP-toxic bivalved molluscs. In: Henshilwood K, Deegan B, McMahon T, Cusack $\mathrm{C}$ and others (eds) Proc 5th Int Conf Mollusc Shellfish Safety, Galway, Ireland, June 14-18, 2004. The Marine Institute, Galway, p 37-42

Pierce R, Henry M, Blum P (2008) Brevetoxin abundance and 
composition during ECOHAB-Florida field monitoring cruises in the Gulf of Mexico. Cont Shelf Res 28:45-58

Poli MA, Mende TJ, Baden DG (1986) Brevetoxins, unique activators of voltage-sensitive sodium channels, bind to specific sites in rat brain synaptosomes. Mol Pharmacol 30:129-135

Roberts BS, Henderson GE, Medlyn RA (1979) The effect of Gymnodinium breve toxin(s) on selected mollusks and crustaceans. In: Taylor DL, Seliger HH (eds) Toxic dinoflagellate blooms. Elsevier, Amsterdam, p 419-424

Roszell LE, Schulman LS, Baden DG (1990) Toxin profiles are dependent on growth stages in cultured Ptychodiscus brevis. In: Granéli E, Sundström B, Edler L, Anderson DM (eds) Toxic marine phytoplankton. Elsevier, New York, NY, p 403-406

Satake M, Campbell A, Van Wagoner RA, Bourdelais AJ, Jacocks H, Baden DG, Wright JLC (2009) Brevisin: an aberrant polycyclic ether structure from the dinoflagellate Karenia brevis and its implications for polyether assembly. J Org Chem 74:989-994

Shimizu Y, Chou HN, Bando H (1986) Structure of brevetoxin A (GB-1 toxin), the most potent toxin in the Florida red tide organism Gymnodinium breve (Ptychodiscus brevis). J Am Chem Soc 108:514-515

Speekmann CL, Hyatt CJ, Buskey EJ (2006) Effects of Karenia brevis diet on RNA:DNA ratios and egg production of Acartia tonsa. Harm Algae 5:693-704

Steidinger KA, Baden DG (1984) Toxic marine dinoflagellates. In: Spector DL (ed) Dinoflagelletes. Academic Press, Orlando, FL, p 201-299

Steidinger KA, Joyce EA (1973) Florida red tides. Florida Department of Natural Resources Marine Research Laboratory Education Series 17, St. Petersburg, FL

Steidinger KA, Vargo GA (1988) Marine dinoflagellate blooms: dynamics and impacts. In: Lembi C, Waaland JR (eds) Algae and human affairs. Cambridge University Press, Cambridge, p 373-401

Steidinger KA, Vargo GA, Tester PA, Tomas CR (1998) Bloom dynamics and physiology of Gymnodinium breve with emphasis on the Gulf of Mexico. In: Anderson DM, Cembella AD, Hallegraeff GM (eds) Physiological ecology of harmful algal blooms. Springer-Verlag, Berlin,

Editorial responsibility: Edward Durbin, Narragansett, Rhode Island, USA p 133-153

Stumpf RP, Ransibrachmanakul V, Steidinger KA, Tester PA (1998) Observations of sea surface temperature and winds associated with Florida, USA, red tides (Gymnodinium breve blooms). In: Reguera B, Blanco J, Fernandez ML, Wyatt T (eds) Harmful algae. Xunta de Galicia and Intergovernmental Oceanographic Commission of UNESCO, Santiago de Compostela, p 145-148

Sunda WG, Granéli E, Gobler CJ (2006) Positive feedback and the development and persistence of ecosystem disruptive algal blooms. J Phycol 42:963-974

Tatters AO, Muhlstein HI, Tomas CR (2009) The hemolytic activity of Karenia selliformis and two clones of Karenia brevis throughout a growth cycle. J Appl Phycol 22: 435-442

Tester PA, Steidinger KA (1997) Gymnodinium breve red tide blooms: initiation, transport, and consequences of surface circulation. Limnol Oceanogr 42:1039-1051

Tester PA, Geesey ME, Vukovich FM (1993) Gymnodinium breve and global warming: What are the possibilities? In: Smayda TJ, Shimizu Y (eds) Toxic phytoplankton blooms in the sea. Elsevier, Amsterdam, p 67-72

$>$ Trainer VL, Baden DG (1999) High affinity binding of red tide neurotoxins to marine mammal brain. Aquat Toxicol 46:139-148

Turner JT, Tester PA (1989) Copepod grazing during an expatriate red tide. In: Cosper EM, Bricelj VM, Carpenter EJ (eds) Novel phytoplankton blooms: causes and impacts of recurrent brown tides and other unusual blooms. Springer, Berlin, p 453-474

Vargo GA, Heil CA, Fanning KA, Dixon LK and others (2008) Nutrient availability in support of Karenia brevis blooms on the central West Florida Shelf: What keeps Karenia blooming? Cont Shelf Res 28:73-98

> Waggett RJ, Tester PA, Place AR (2008) Anti-grazing properties of the toxic dinoflagellate Karlodinium veneficum during predator-prey interactions with the copepod Acartia tonsa. Mar Ecol Prog Ser 366:31-42

Watras CJ, Garcon VC, Olson RJ, Chisholm SW, Anderson DM (1985) The effect of zooplankton grazing on estuarine blooms of the toxic dinoflagellate Gonyaulax tamarensis. J Plankton Res 7:891-908

Submitted: March 29, 2011; Accepted: September 15, 2011 Proofs received from author(s): December 14, 2011 